\title{
9. Do You Want it Gift Wrapped?: Protecting Traditional Knowledge in the Pacific Island Countries
}

\author{
Miranda Forsyth
}

The importance of customary law and customary institutions in the context of protecting the traditional knowledge $(\mathrm{TK})^{1}$ of indigenous people is gradually being more widely recognised. ${ }^{2}$ However, translating this recognition into practice still seems a long way off, as very few countries have developed a protection framework that provides a role for customary institutions. ${ }^{3}$ The Pacific Island countries are currently in the process of moving forward with such an initiative, and their experiences offer important insights into the challenges associated with it. This chapter begins by discussing the TK agenda as it has been pursued in the region for the past decade, and in particular the development of the Regional Framework for the Protection of Traditional Knowledge and Expressions of Culture (2002), which has been cited as a best practice approach. ${ }^{4}$

The Pacific Island countries have approached the protection of what may be called 'traditional cultural expressions' separately from the protection of biological knowledge, innovations and practices, ${ }^{5}$ and as a result the scope of this

\footnotetext{
1 There are many definitions of TK in the academic and grey literature and draft legislation: see, for example, Antons' summary in C Antons (ed), Traditional Knowledge, Traditional Cultural Expressions and Intellectual Property Law in the Asia-Pacific Region (Kluwer Law International, 2009) 1-4. For the purposes of this chapter the definition provided in the Model Law is adopted, namely: 'traditional knowledge includes any knowledge that generally (a) is or has been created, acquired or inspired for traditional economic, spiritual, ritual, narrative, decorative or recreational purposes; and (b) is or has been transmitted from generation to generation; and (c) is regarded as pertaining to a particular traditional group, clan or community of people; and $(\mathrm{d})$ is collectively originated and held'.

2 See Articles 18 and 31 of UNDRIP; Articles 8(j) and 10(c) of CBD; and the many references to customary law in the World Intellectual Property Organization's Intergovernmental Committee on Intellectual Property and Genetic Resources, Traditional Knowledge and Folklore, The Protection of Traditional Cultural Expressions/ Expressions of Folklore: Revised Objectives and Principles (2010) <http://www.wipo.int/edocs/mdocs/tk/en/ wipo_grtkf_ic_17/wipo_grtkf_ic_17_4.pdf>

3 Case studies of some countries that are attempting this are presented in International Institute for the Environment and Development, Protecting Community Rights over Traditional Knowledge Project (2005-2009) $<$ http://www.iied.org/natural-resources/key-issues/biodiversity-and-conservation/protecting-communityrights-over-tradition $>$

4 See, for example, I Abeyesekere, 'The Protection of Expressions of Folklore in Sri Lanka' in Antons, above n 1, 341, 347; S von Lewinski, 'An Analysis of WIPO's Latest Proposal and the Model Law 2002 of the Pacific Community for the Protection of Traditional Cultural Expressions' in Antons, above n 1, 109, 119.

5 These are dealt with in the recent Model Law on Traditional Biological Knowledge, Innovations and Practices $<$ http://www.sprep.org/legal/documents/MLv11.doc4Apr_000.pdf> The separation between these two types of TK could be argued to be unhelpful and as undermining an attempt to view TK as holistically as possible.
} 
chapter is limited to the TK that is found in songs, stories, oral traditions, visual and performing arts, ritual and cultural practices, and architectural forms. ${ }^{6}$ The chapter then builds the case that existing customary law and institutions are central to TK, and that this mandates the adoption of a pluralistic approach to the protection of TK. It then demonstrates that the current approach towards TK in the Pacific Island countries is not a truly (or deeply) pluralistic one, despite the many references to customary law and institutions in the legislation and policy documents. Moreover, it is based on a number of assumptions about the nature of customary law and the reach of state law and state institutions in the region that may not be valid. Following suggestions from academics such as Boyle ${ }^{7}$ and Drahos $^{8}$ to look at the disadvantages as well as the advantages of extending the reach of any type of intellectual property protection, I then identify a number of problems that are likely to flow from an implementation of the current state-centric approach. In conclusion, the chapter outlines what a more pluralistic approach to the protection of TK in any jurisdiction would involve.

The main aim of the chapter is to urge caution with moves towards the protection of TK and to stress the necessity of properly respecting the existing customary regulatory structure that almost certainly exists in every country in which TK is present. The protection of TK by the state, which inevitably involves the creation of new rights and owners of those rights, is not self-evidently a step forward for indigenous people, and even risks endangering the TK it sets out to protect. Boyle's caution that 'when you set up property rule in some new space, you determine much about the history that follows ${ }^{\prime 9}$ is thus equally as apposite in the TK context as in that of genes and databases.

I acknowledge that I have already commented on the Model Law when it was first enacted in 2002. ${ }^{10}$ Although the law itself has not changed since, my views of it have altered radically in the intervening period. This is largely a result of the intensive study of customary law in Vanuatu undertaken in 2002 to 2008, a field with which I was unfamiliar when I first encountered the Model Law. This study ${ }^{11}$ and my understanding of the theory of legal pluralism inform the observations I make concerning customary law in this chapter.

6 For a complete description see section 4 of the Model Law.

7 J Boyle, The Public Domain (Yale University Press, 2008) 56.

8 P Drahos with J Braithwaite, Information Feudalism (The New Press, 2002) ix.

9 J Boyle, above $n$ 7, 56.

10 M Forsyth, 'Cargo Cults and Intellectual Property in the South Pacific' (2003) 14 Australian Intellectual Property Journal 193.

11 M Forsyth, A Bird that Flies with Two Wings: Kastom and State Justice Systems in Vanuatu (2009) <http:// epress.anu.edu.au/kastom_citation.html> 


\section{The Traditional Knowledge Agenda in the Pacific Island Countries}

The move to protect TK in the region has been proceeding in fits and starts for over a decade. A Symposium on the Protection of Traditional Knowledge and Expressions of Indigenous Cultures in the Pacific Islands held by the United Nations Educational, Scientific and Cultural Organization (UNESCO) in 1999 concluded with a Declaration that recommended technical assistance and support for 'a homogeneous system of legal protection, identification, conservation and control of exploitation, of indigenous culture'.$^{12}$ This led to the production of the Model Law by the Secretariat of the Pacific Community in 2002. ${ }^{13}$

The movement for protection of TK thus began at a very high policy level, and at the initiative of international and regional, rather than local, institutions and actors. Right from the start it is possible to identify a number of different, and arguably competing, aims for TK legislation, all covered by the amorphous term 'protection'. Three main concepts associated with the term can be distilled: the conservation of TK in the face of pressures resulting from rapid social change; the misappropriation of $\mathrm{TK}$; and the facilitation of commercialisation of TK by the TK holders themselves. All these different aims are present in the regional documents concerning TK, although to date there has been little acknowledgment of the fact that conservation of cultural heritage and traditions may well be incompatible with the establishment of a structure that facilitates their commercialisation. ${ }^{14}$ A similar conflation of aims was identified in Papua New Guinea by Kalinoe, who argues that the difficulty in finding a suitable model for protection may in part be because people have been misled into thinking that these matters can be comfortably housed together' ${ }^{15}$

The Model Law was adopted by the Forum Trade Ministers in 2003. In many ways it follows the general contours established by the UNESCO-World Intellectual Property Organization (WIPO) Model Provisions for National Laws on the Protection of Expressions of Folklore Against Illicit Exploitation and Other Prejudicial Actions (1985). It confers upon owners of TK the right to authorise others to exploit their TK, and to prevent others from exploiting it

\footnotetext{
12 UNESCO, Symposium on the Protection of Traditional Knowledge and Expressions of Indigenous Cultures in the Pacific Islands (1999) <http://portal.unesco.org/culture/en/files/14264/10645002355Noumea1999.pdf/ Noumea1999.pdf>

13 Above $\mathrm{n} 5$.

14 For an exception to this see K Serrano and M Stefanova, 'Between International Law, Kastom and Sustainable Development: Cultural Heritage in Vanuatu' in G Baldaccino and D Niles (eds), Island Futures: Conservation and Development Across the Asia-Pacific Region (Springer, 2011) 19.

15 L Kalinoe, 'Ascertaining the Nature of Indigenous Intellectual and Cultural Property and Traditional Knowledge \& the Search for Legal Options in Regulating Access in Papua New Guinea' (2007) 27 Melanesian Law Journal 1, 8.
} 
without their free, prior informed and full consent. It requires the authorisation to be in writing and to be approved by an expressly created national authority. Until 2009 there was little movement by individual countries in respect of implementing the law, but in that year the issue gained momentum with the creation of the Traditional Knowledge Implementation Action Plan (2009) (Action Plan). ${ }^{16}$ The Action Plan is being implemented by the Forum Secretariat working with the Trade Commission, WIPO, the Secretariat of the Pacific Community (SPC) and Secretariat of the Pacific Regional Environmental Program, and is said to be based on a mandate of Forum Trade Ministers and the Forum Leaders' directives in the Pacific Plan (2005). ${ }^{17}$ Perhaps not surprisingly, given the partners involved and the trade context in which it has developed, the Action Plan prioritises the commercialisation of TK over any other objective, stating 'Improved policy transparency, the creation of a supportive environment for private sector expansion and economic growth, and assuring accountability and good governance underpin the Action Plan. ${ }^{18}$ As of 2011, there were six countries drafting a national law based on the Model Law. ${ }^{19}$ Of these, the only publicly available draft is that of Palau, which produced a Bill in 2005, but this has not yet been passed by its legislature. ${ }^{20}$

The Action Plan has a clear regionalisation agenda. A press statement refers to 'uniform national legal systems of protection'21 and envisages a 'regional arrangement of mutual recognition and enforcement regime to protect and promote TK use'.$^{22}$ This regionalisation agenda is far more muted in the Model Law, which merely urges countries to adopt and adapt the Model as they see fit. It raises an important question about the expected reach of the legislation - or, to put it in another way, who is the intended target of the regulation?

To answer this it is necessary to examine the stated aims of the legislation. The Action Plan articulates the driving rationale as being that the 'continued exposure of Pacific TK to improper exploitation without due compensation demands that a regional approach be adopted as a matter of urgency while an international regime is being finalized' ${ }^{23}$ Leaving aside the fact that no empirical

16 Pacific Islands Forum Secretariat, Traditional Knowledge Implementation Action Plan (2009) <http:// www.forumsec.org.fj/resources/uploads/attachments/documents/Traditional \%20Knowledge \% 20Action $\% 20$ Plan\%202009.pdf>

17 Ibid, 2.

18 Ibid.

19 Ibid.

20 A Bill for an Act to establish a sui generis system for the protection and promotion of 'Traditional Knowledge and Expressions of Culture for the people of the Republic of Palau' (2005) <http://www.palauoek. net/senate/legislation/sb/sb_7-3.pdf >

21 Pacific Islands Forum Secretariat, 'TK Implementation Action Plan Progressing Well' (Press Release, 27 September 2010) < http://www.forumsec.org.fj/pages.cfm/newsroom/press-statements/2010/tk-implementationaction-plan-progressing-well.html>

22 Ibid.

23 Pacific Islands Forum Secretariat, above n 16, 3. It must be observed that the international protection regime is, unfortunately, very far from being finalised. 
study is presented or cited to substantiate this belief, national or even regional legislation is unlikely to prevent this from occurring. With the exception of Fiji and possibly Samoa, the manufacturing capacity of most countries in the region is very limited, and therefore any mass production is likely to occur outside the jurisdictional limits of all the countries involved. The legislation must therefore primarily be considered in terms of its regulatory effects on the Pacific Islanders themselves, and their exceedingly small populations of non-indigenous citizens (except in Fiji). There is arguably thus little to be gained by working towards a uniform regional approach and, as discussed below, much to be lost from failing to take into account local differences across the region.

This brief discussion has argued that the movement to protect TK in the region is currently largely driven by economic considerations and is being pursued in a state-centred way. The next section argues that a different approach, one that supports, rather than cuts across, customary institutions in regulating TK, would be preferable for the region.

\section{The Need for a Pluralistic Approach to Protection of TK}

To understand the importance of a pluralistic approach to TK, the centrality of customary law and institutions to TK must be appreciated. This section briefly discusses the nature of customary laws and institutions in the region, and then goes on to demonstrate their inter-relatedness with TK and the social and economic underpinnings of the communities to which they belong. As Drahos argues, 'systems are nested phenomena', ${ }^{24}$ and the customary law system in all countries is nested within particular economic and social systems. The third part of this section then argues that adopting a pluralistic approach to regulating TK would nurture the relationship between customary laws and institutions, even in the context of a nation state.

\section{(a) The Nature of Customary Laws and Institutions in the Pacific Island Countries}

Whilst it is extremely difficult to make any generalisation about a region as diverse as the Pacific Islands, it is true to say that despite the forces of colonisation, decolonisation and the creation of independent liberal nation states, every one of the Pacific Island countries continues to have an indigenous

24 P Drahos, 'Six Minutes to Midnight: Can Intellectual Property Save the World?' in K Bowery, M Handler, and D Nichol (eds), Emerging Challenges in Intellectual Property (Oxford University Press, 2011) 30. 
system of governance that exists largely independent of the state. ${ }^{25}$ This system is generally administered at a community level by traditional leaders, known as chiefs in some places and 'old men' or 'big men' in others. These leaders were traditionally responsible for regulating all aspects of the social and economic relationships in their communities, and today continue to be responsible for a great many of them, especially in areas least affected by the cash economy and the institutions of the nation state. ${ }^{26}$ This regulation is done through the use of established community norms (both explicit and implicit) and, perhaps more importantly, an autochthonous process of conflict management that varies across the region. This process is based on various principles, which vary from community to community and country to country, but are mostly restorative in nature and concerned with maintaining community peace. These principles are employed by the leaders, using various established procedures such as community meetings, to arrive at solutions that manage all community and intercommunity disputes, including those over TK. For example, an anthropologist working with the Zia people in Papua New Guinea observes:

From my work, it seems clear that there are set systems, patterns, procedures and rules involved in dispersing certain property. Also there are types of information available. Information that is general, specific, magical, ritual, sacred, secret, spiritual, etc, which is processed in accordance with the rules, how that information relates to a possessor (could be a group, individual, spirit, gender related etc)...cultural property exists within flows of transactions that are as intricate and precisely executed as those of an ecosystem. ${ }^{27}$

The system as a whole is dynamic and driven by the needs of a particular dispute or event, rather than by concerns to lay down a prescriptive normative framework. In other words, customary law, including that concerning TK, is continually evolving and is in many ways an ongoing dialogue about the way things should be done in the community, mediated by the customary leaders.

It is also true to say that in every country in the region these customary institutions are under a great deal of pressure as a result of both rapid social change in the region over the past several decades and the challenges of competing state governance structures. ${ }^{28}$ Customary laws and institutions are

\footnotetext{
25 For example, the village fono system in Samoa, the kastom system in Vanuatu and the maneaba in Kiribati, to name a few.

26 See R Regenvanu, 'The Traditional Economy as the Source of Resilience in Melanesia' (Paper presented at the Lowy Institute Conference 'The Pacific Islands and the World: The Global Economic Crisis,' 2009).

27 S Kamene and K Sykes, 'The Work of the Zia Trust: A Holistic Extended Case Study from the Waria River Valley, Morobe' in K Sykes, J Simet and S Kamene (eds), Culture and Cultural Property in the New Guinea Islands Region: Seven Case Studies (UBSPD, 2001) 18.

28 In the context of Vanuatu, see for example Forsyth, above $\mathrm{n} 11$.
} 
thus just as vulnerable to extinction as other aspects of TK, and hence strategies for their reinforcement must be considered at the same time as protection of TK for the reasons discussed below.

\section{(b) The Centrality of Customary Laws and Institutions to TK}

Customary law and institutions currently regulate entitlements to TK, but TK and customary law are linked in an even more fundamental way. Thus, while traditional leaders, institutions and laws are central to social and economic relations in the Pacific Island countries, TK is the very 'stuff' with which those social and economic relations are woven (and that dreams are made of - see below). For example, TK is crucial in determining leadership status, agricultural practices, navigation and trade routes, ceremonial practices, rights to land and land use, spiritual beliefs, healing practices, social organisation, concepts of belonging and exchange networks. Du Plessis and Fairbairn-Dunlop argue:

The indigenous knowledge systems of the Pacific incorporate technical insights and detailed observations of natural, social and spiritual phenomena, which in turn are used to validate what is important in life - what sustains people and what connects them to particular places and spaces, and is crucial to their identity... In Pacific communities, knowledge is communally made, sanctioned, shared and used with the aim of achieving the good life for all members - however this is defined. ${ }^{29}$

Even the development of new knowledge is rooted in communal sources. Thus Lindstrom observes:

Islanders do not explain their production of songs or other new knowledge in terms of a knower's individual talent, genius or creativity. Local epistemology seeks authorities and not individual authors...the Tannese intimate that they are repeating truths told by their fathers, whispered by spirits when intoxicated by kava, or revealed by ancestors in dreams. ${ }^{30}$

TK is often intimately bound up with social organisation in a particular community because access to it may be possessed only by certain members of that community. For example, knowledge about a particular ancestor-creator may be limited to people of certain status in a particular community. Thus, Whimp, in a study of Papua New Guinea, observes:

29 R Du Plessis and P Fairbairn-Dunlop, The Ethics of Knowledge Production — Pacific Challenges (UNESCO 2009) 100-111.

30 L Lindstrom, 'Big Men as Ancestors' (1990) 29 (4) Ethnology 313, 316. 
At least in some Papua New Guinea societies, the value of knowledge, for example, is inversely related to the number of people who possess it. The more people who know something, the less significant it is assumed to be. Restricting access to knowledge can reinforce cultural identity and strengthen social hierarchies and inequalities. ${ }^{31}$

The exchange of TK is also important to the maintenance and development of social networks. Busse and Whimp argue that 'the primary purpose and result of gift exchanges are to establish and maintain relations between persons making such exchanges' ${ }^{32}$ and that 'the power of gift exchanges to create enduring social relationships lies precisely in the fact that the objects given are not completely alienated'. ${ }^{33}$ The fruitful exchange of TK, which also stimulates the production of new TK, is facilitated in part by the decentralised nature of the customary laws and institutions that regulate it today.

Many anthropologists have commented upon the difficulty of divorcing the materiality of objects from their immateriality in this region. Jolly argues that 'the materiality of these objects [so-called primitive art] could not be so easily divorced from immateriality, the meanings, the ideas, the relations, the values, the agency with which they were endowed by their creators, users and original spectators'. ${ }^{34}$ Bolton, for example, sees woven pandanus mats 'not as objects but as the materialisation of relations, as animated agents, like persons; their importance is "not what they mean, but what they do". 35

This discussion of the nature of TK and of customary norms has at least two important ramifications for the protection of TK. The first is that neither TK nor customary norms can sensibly be separated from the social processes in which they have been developed, although this is often what Western reforms such as the Model Law attempt to do. A holistic approach is therefore necessary one that sees TK in what Sillitoe calls 'a wider cultural context'. ${ }^{36}$ The second is that it is difficult to boil down the multiple links and resonances that TK has within the community of which it is a part to a single 'right' that is 'owned' by a clearly defined group of people. Moreover, there can be all sorts of ramifications flowing from unauthorised access to TK that can only be dealt with by the

\footnotetext{
31 K Whimp and M Busse (eds), Protection of Intellectual, Biological and Cultural Property in Papua New Guinea (Oceania Publication, 2002) 19.

32 Ibid, 17.

33 Ibid, 18.

34 M Jolly, 'Material and Immaterial Relations: Gender, Rank and Christianity in Vanuatu' in L Dousset and S Tcherkezoff (eds), The Scope of Anthropology (Berghahn Books, 2012) 110.

35 Ibid.

36 P Sillitoe, 'Trust in Development: Some Implications of Knowing in Indigenous Knowledge' (2010) 16 Journal of the Royal Anthropological Institute 12, 15.
} 
community leaders. These observations suggest that it is unwise to equate customary entitlements to access to TK with 'ownership' ${ }^{37}$ and that the best people to regulate access to TK are the customary leaders themselves.

\section{(c) Weak and Deep Legal Pluralism}

The aim of this section is to demonstrate that recognition of the centrality of customary law and customary institutions to TK dictates the adoption of a deep pluralist approach to TK. Such an approach involves the construction of a framework that supports the relevant customary institutions and allows them room to operate by themselves, rather than subsuming them within a state structure. This approach can be contrasted with so-called 'weak' legal pluralism, where customary norms are removed from their institutional context and applied by the state system. ${ }^{38}$ In other words, deep legal pluralism involves the co-existence of legal orders with different sources of authority, whereas in weak legal pluralism there is only one legal order (the state) drawing upon two different bodies of norms. ${ }^{39}$ As Griffiths observes, '[T]hese two perspectives give rise to different strategies for dealing with customary law namely whether to work for recognition of customary law within the state national legal system, or whether to claim recognition for it outside this system. ${ }^{40}$

To date, these two different types of approaches have not been clearly differentiated in much of the literature concerning TK. The result is that weak legal pluralism is often being advocated as the appropriate way to recognise customary law and institutions. For example, Pigliasco argues: 'The question that arises is not whether or not the sanctions of customary law are applicable to outsiders, but rather the extent to which the rights relating to cultural expressions - as granted by custom to certain traditional custodians - are recognized by national legislations, and thus could be enforced.'41 Kruk similarly states: 'Customary law would remain an effective method of protecting traditional knowledge only insofar as it is recognised and applied in national legal systems by the courts. ${ }^{42} \mathrm{He}$ advocates attempts 'to recognize formally the legal status of customary law in the legal system and then to improve on the current methods of ascertaining and applying rules relating to traditional

\footnotetext{
37 This point is convincingly made in Kalinoe's excellent paper on TK in Papua New Guinea: L Kalinoe, above $\mathrm{n} \mathrm{15,1,6-8.}$

38 See J Griffiths, 'What is Legal Pluralism?' (1986) 24 Journal of Legal Pluralism 1.

39 Forsyth, above $\mathrm{n} \mathrm{11,43.}$

40 A Griffiths, 'Customary Law in a Transnational World: Legal Pluralism Revisited' in R A Benton (ed), Conversing with the Ancestors: Concepts and Institutions in Polynesian Customary Law (Te Matahauariki Institute, University of Waikato, 2006) 9. See also M Davies, 'The Ethos of Pluralism' (2005) 27(1) Sydney Law Review 87.

41 G Pigliasco, 'Visual Anthropology and Jurisprudence: The Sawau Project' (2007) Anthropology News, 65. 42 P Kruk, 'The Role of Customary Law Under Sui Generis Frameworks of Intellectual Property Rights in Traditional and Indigenous Knowledge' (2007) 17 Indiana International and Comparative Law Review 67, 101-102.
} 
knowledge'.$^{43}$ Antons also observes that 'stronger recognition of customary law principles could be very helpful in resolving some of the issues surrounding traditional knowledge', and then states: 'The big question is, however, how to integrate them into the state legal system. ${ }^{44}$ The error of this type of approach is in assuming it is possible to take customary norms out of their context and have them applied by a foreign system. As discussed above, norms, procedures and knowledge are interwoven in a complex and dynamic way, at least in the Pacific Island countries and probably in most indigenous legal systems, meaning that an exercise such as that which Pigliasco and Kruk advocate is not possible.

There are some who take a broader view, particularly indigenous scholars and anthropologists. For example, Solomon argues in a Māori context that there is a 'need to give priority to the strengthening and development of existing customary law systems, which reflect and nourish the underlying values of the relevant cultures and associated biodiversity' ${ }^{45}$ Whimp also argues: 'In considering laws to explicitly protect rights in intellectual property, it is critical that Papua New Guinean ideas about ownership, property, knowledge, and creativity are taken into account if those laws are to reflect the contemporary social and political contexts in which they will be applied. ${ }^{\prime 46}$ Most recently the International Institute for Environment and Development has recommended that customary law and customary authorities should be central to the development of protection systems. ${ }^{47}$ However, to date no one has articulated how this can be done in practice. An attempt is made to do this in the last part of this chapter.

\section{A Pluralistic Analysis of the Model Law and Action Plan}

This section uses the theory of legal pluralism discussed in the preceding section to analyse the extent to which the Model Law and associated initiatives support customary law and institutions both procedurally and substantively. To date, academic commentary on the Model Law has been positive and has praised the Model Law's extensive references to customary law. ${ }^{48}$ My analysis below is more critical.

\footnotetext{
43 Ibid, 116.

44 C Antons, 'The International Debate about Traditional Knowledge and Approaches in the Asia-Pacific Region' in Antons, above n 1, 39, 49.

45 M Solomon, 'Strengthening Traditional Knowledge Systems and Customary Laws' in S Twarog and P Kapoor (eds), Protecting and Promoting Traditional Knowledge: Systems, National Experiences and International Dimensions (United Nations, 2004) 155.

46 Whimp, above $\mathrm{n} 31,21$.

47 IIED, Protecting Community Rights Over Traditional Knowledge: Implications of Customary Laws and Practices: Key Findings and Recommendations (2005-2009) <http://www.iied.org/pubs/pdfs/G02583.pdf>

48 G Pigliasco, 'Intangible Cultural Property, Tangible Databases, Visible Debates: The Sawau Project' (2009) 16 International Journal of Cultural Property 255, 262-263; S von Lewinski, above n 4, 109, 119, 124.
} 
On a procedural level, the TK initiative in the region has been almost entirely state focused. The top-down approach outlined in the Action Plan emphasises the drafting of legislation as an initial step, and envisages community consultation as occurring only significantly down the track. Even then, the community consultation is not seen primarily as a way of developing the framework along with the community leaders, but rather as an opportunity for TK owners to 'understand the implications of the Model Law and the effect of subsequent proposed legislation on their resources' ${ }^{49}$ The exploration of a possible role for customary laws and practices is regarded as only a 'medium-term period' activity. ${ }^{50}$ This state-centred approach is also supported by various official statements. For example, the Director of the Institute of Fijian Language and Culture states that in Fiji 'We have a legal consultant who is finally working with this national law which will come into effect in 2010. So we hope that the law will also be taken down to the grassroots people, the owners and custodians of ICH in consultations, so their views will be heard and that the law will be amended accordingly. ${ }^{51}$ The problem with this approach is that it is significantly more difficult to alter a law once it has been drafted or even enacted than it is at the policy development stage: by then the general contours of the framework are fixed and there is relatively little room to negotiate. A far preferable approach would be to conduct research into the customary institutions and laws involved as a first step, and to consult widely amongst TK holders and customary leaders before drafting any laws. Ironically, the Action Plan refers to the importance of adopting a 'bottom-up' ${ }^{52}$ and holistic approach ${ }^{53}$ while outlining the opposite.

On a substantive level, at first and even second and third glances, the Model Law appears to create a central role for both customary law and customary institutions. The decisions concerning access are delegated to TK holders, and responsibilities given to customary institutions to, for example, decide ownership. However, a close analysis demonstrates that it is not a truly pluralistic law. It establishes a system and a value structure that are predicated upon certain views of TK, customary law and the type of protection that is important, and assumes that TK holders and customary institutions will just slot into them. The misfit between the aim of the legislation to be sensitive to customary law and the reality that it is not sensitive to it arises because the legislation is based upon a view of both TK and customary law as inert, so that clearly defined chunks of content can be removed from their context and still

\footnotetext{
49 Action Plan, above n 16, 5.

50 Action Plan, above n 16, 4.

51 M Qereqeretabua, 'The Safeguarding of Intangible Cultural Heritage in Fiji' (Paper presented at the International Seminar on the Safeguarding of Intangible Cultural Heritage: Current Situations and Challenges on the Safeguarding measures in the Asia-Pacific Region, 14 January 2010) 3 <http://www.tobunken. go.jp/ geino/e/ISSICH/IS2010.html>

52 Action Plan, above n 16, 3.

53 Action Plan, above n 16, 6.
} 
make sense. However, as we have seen above, both are dynamic, amorphous and interactive. To demonstrate these points, this section now discusses four ways the Model Law refers to customary law and institutions.

\section{(a) The Distinction Between Customary and Non- customary Use}

The Model Law draws a distinction between customary and non-customary use, and intends to regulate only the latter. However, it is no simple matter to determine what is meant by 'customary use', given the constantly changing nature of custom. The legislation defines customary use as 'use of traditional knowledge or expressions of culture in accordance with the customary laws and practices of the traditional owners' ${ }^{54}$ This does not, however, make it clear whether permission to use the TK following the custom of the relevant community is required, or if the use must be permitted by the custom of the relevant community. If it came to a dispute about this issue, it would be a matter for the courts rather than the customary institutions to decide, as they have prima facie jurisdiction over all disputes concerning state legislation. Lacking the flexible processes that underpin customary institutions, the courts could answer this question only by looking at precedents established by customary laws in the past. The consequence of this provision is that the Act is in effect making a division between traditional and new uses of TK, and mandating the involvement of the state in the latter.

These arguments may be better followed in the context of an example drawn from one of the very few court cases in the region that involves TK: the 'Nagol jump' dispute in Pentecost, one of the islands that comprise the country of Vanuatu. The facts of this case are set out in the Supreme Court's judgment, ${ }^{55}$ but the essentials can be summarised as follows.

The Nagol jump is an important tradition in a number of villages on South Pentecost. ${ }^{56}$ It involves men jumping from a specially constructed high tower to which they are tethered by vines tied to their ankles. Ideally, the vines are exactly the right length for the men neither to crash to their death nor be jerked back violently into the tower. In 1992 a group of men from South Pentecost (group X) decided that they were not adequately profiting from the tourism that has come from the Nagol jump, so proposed performing the jump on another island, Santo. They started negotiations with the relevant chiefly council,

\footnotetext{
54 Model Law, above n 5, s 4.

55 In re the Nagol Jump, Assal \& Vatu v the Council of Chiefs of Santo [1992] VUSC $5<$ http://www.paclii.org.vu>

56 See M Jolly, 'Kastom as Commodity: The Land Dive as Indigenous Rite and Tourist Spectacle in Vanuatu' in L Lindstrom and G White (eds), Culture, Kastom, Tradition: Developing Cultural Policy in Melanesia (Institute of Pacific Studies, University of the South Pacific, 1994) 131, 141.
} 
and the head of the council agreed that the jump could be done for the three following years, provided the National Council of Chiefs (NCC) agreed. The head of the council then went to the capital, Port Vila, to negotiate with the NCC. In his absence a number of the group decided to go ahead without waiting for his return. They were warned by customary leaders not to do so, but refused to listen. When they got to Santo they were met by the relevant chiefs there and told to pay a fine and to return to Pentecost to start discussions. Group X then applied to the Supreme Court for a declaration that their constitutional rights had been breached. ${ }^{57}$

So, is taking the jump to Santo customary use or not? According to the judgment, the Nagol had been performed outside Pentecost on two previous occasions for particular reasons. Arguably, therefore, taking it to Santo was not completely without precedent and could still be regarded as a customary use. On the other hand, it could be argued that it was a non-customary use, as the proper procedures for applying for it to be taken to Santo were not followed, and its historical association with Pentecost means its performance there is central to its very rationale. ${ }^{58}$ This example demonstrates that there is not always a clear distinction between customary and non-customary use, and that customary institutions are able to deal in a fair and innovative way with new uses of TK. It also suggests the need to be careful before transferring jurisdiction over such disputes to the state or creating new avenues for 'appealing' and hence undermining decisions made by customary authorities (as occurred in the example case).

\section{(b) Determining Ownership}

It can be assumed that ownership is likely to be controversial in many cases, especially if there is the real or imaginary prospect of a windfall gain. One has only to look at the bitter disputes that have accompanied the return of land to customary 'owners' when countries become independent and the distribution of royalties from resource developments across Melanesia to visualise the

\footnotetext{
57 They claimed that their rights under sections $5(1)(\mathrm{g}),(\mathrm{h})$, (i) and $(\mathrm{k})$ were breached. These are the rights to freedom of expression, freedom of assembly and association, freedom of movement, and equal treatment before the law. The court found there was no relevant law applicable and therefore it was necessary to follow section 47(1) of the Constitution, requiring the court to determine the matter according to 'substantial justice' and if at all possible in conformity with custom. His Honour then ordered that the Nagol jumping should return to Pentecost and that any future decision for it to leave Pentecost should only occur with the majority consent of the custom owners taken on a vote. This appears never to have occurred and the Nagol jump has remained in Pentecost. This case is in many ways a success, as the state legal system was able to reinforce the customary system. However, it was largely dependent upon the proclivities of the particular judge as there was no guiding law, and his Honour imposed a requirement on the movement of the Nagol (the requirement of a vote) that was uncalled for by the customary leaders and to an extent cut across their authority over the matter.
}

58 See Jolly, above n 34 . 
potential difficulties involved in determining rights to certain aspects of cultural heritage. ${ }^{59}$ As with land, the problems of determining the limits of entitlement to TK claims are compounded by the movement of communities as a result of missionisation, plantation labour, epidemics and, more recently, urban drift. ${ }^{60}$ The potential complexities of ownership can be illustrated by Lindstom's description of rights to kava in Vanuatu:

[i]ndividuals (and their families and lineages) may claim overlapping rights to this or that kava variety, and would deny common cultural heritage. There are also (chiefly) titled versus untitled, and male versus female, claims to use and exchange kava. On the island of Tanna, for example, certain families have the right to consume specially grown and decorated kava tapunga at festivals celebrating boys' circumcisions. Overlapping claims to this sort of kava by scattered families across the island would be difficult to adjudicate. Any sui generis patent system that awarded general rights to kava to all ni-Vanuatu, or to the state, also could spark opposition from individuals, regions, kin-groups, and classes jealous of their particular kava claims. ${ }^{61}$

By introducing the concept of 'ownership' of TK by a finite group of people whose rights are backed by the state, the Model Law is therefore introducing a new and almost certainly troublesome concept into the regulation of TK in the region. The fact that it recognises that there may be communal or individual ownership does not avoid the difficulties that are likely to arise in determining the membership of the ownership group.

Under the Model Law, once a request to the cultural authority (CA) is made by a prospective user of $\mathrm{TK}$, the $\mathrm{CA}$ is responsible for identifying the owners of the TK. This must be done by publishing a copy of the application in a newspaper and, if appropriate, on the radio or television. ${ }^{62}$ The owners then have twentyeight days to advise the CA of their claim. Then if the CA 'is satisfied that it has identified all the traditional owners' it must make a written determination. ${ }^{63}$ There are no criteria to assist it in determining what standard of satisfaction is required. The only requirement is that the CA note down the parties who have advised they are the owners, and make a written decision and then publish

59 See, for example, C Filer, 'Grass Roots and Deep Holes: Community Responses to Mining in Melanesia' (2006) 18(2) Contemporary Pacific 215; N Haley and R May, Conflict and Resource Development in the Southern Highlands of Papua New Guinea (ANU E Press, 2007); J Bennett, 'Roots of Conflict in Solomon Islands Though Much is Taken, Much Abides: Legacies of Tradition and Colonialism' (Discussion Paper, 2002/5 State, Society and Governance in Melanesia, 2002) < http://dspace.anu.edu.au/bitstream/1885/41835/2/bennett02-5. pdf> G Hassall, 'Conflict in the Pacific: Challenges for Governance' (2005) 20(1) Pacific Economic Bulletin 192. 60 See Jolly, above n 34, 141.

61 L Lindstrom, 'Kava Pirates in Vanuatu?' (2009) 16 International Journal of Cultural Property 291, 299-300.

62 Model Law, above n 5, s 16.

63 Model Law, above n 5, s 17. 
it. This determination then provides a conclusive defence for any user of TK if the traditional owners specified in the determination have given their prior informed consent to the use. ${ }^{64}$ This means that there is no effective way for contesting owners to appeal the CA's decision about ownership.

If the CA is not satisfied it has identified all the owners, or if there is a dispute, the CA 'must refer the matter to the persons concerned to be resolved according to customary law and practice or such other means as are agreed to by the parties' ${ }^{65}$ This is the closest the legislation comes to deep pluralism, and is clearly a step in the right direction. However, very clear thinking and development with the relevant customary institutions and leaders will be needed at the national implementation stage. It is not enough to create a new and controversial concept, and then to delegate responsibility for resolving claims to it to customary authorities without prior consultation. It is especially unfair to require customary authorities to deal with such claims within the presumably limited timeframe set down in the legislation. If the experiences of customary land tenure in the region are anything to go by, these are going to be particularly thorny issues that could generate a great deal of internal community conflict. Customary institutions must therefore be properly supported in preparation for such responsibility.

If the CA is satisfied that no owners can be identified or no agreement has been reached on ownership within the period set out in the legislation, it may take the somewhat draconian measure of making a determination that the CA is the traditional owner. ${ }^{66}$ The only guidance given about whether or not the CA should make this decision is to consult with the relevant Minister. The CA is then free to enter into an agreement with the prospective user or not, with no guidance provided as to what should drive the decision-making (such as, for example, the views of the ownership contestants). The only limitation on the CA's power is that any benefits arising under the agreement must be used for traditional cultural development purposes. It is interesting that the possibility of holding them in trust until ownership is determined is not an option. This is the approach that has been taken in the Palau legislation, and seems preferable. ${ }^{67}$ In other respects, however, the Palauan approach to ownership is far more unreasonable: the legislation provides that all the TK in Palau belongs to the state until ownership is proven otherwise. ${ }^{68}$

64 Model Law, above n 5, s 32.

65 Model Law, above n 5, s 18(1).

66 Model Law, above n 5, s 19.

67 Bill, above n 20, s 16.

68 Ibid. 


\section{(c) Requirement of State Assent for Use of TK by a Pacific Islander}

The Act is unclear about what rights a member of a community of traditional owners has with regard to TK. It appears that a member of the TK-holding community needs to get the prior informed consent of the other members of the community if he or she wants to use the TK in a way that is non-customary. Thus, the explanatory memorandum (EM) notes, 'if [a] person intends to perform [a dance from his/her community] in a non-customary way, for example performing the dance in non-customary costumes and with non-customary music, the person must obtain the prior and informed consent of the traditional owners as set out in Part 4'. This explanation also seems to suggest that 'customary use' is synonymous with 'traditional use' as discussed above.

To make matters more complicated, it is not enough to get the prior informed consent of all the owners. It is also necessary to involve the state - at the bare minimum, by advising the CA that the potential user has sought the prior informed consent of the other traditional owners, filling out a copy of the proposed user agreement, submitting it to the CA for advice, and providing a copy of the signed authorised user agreement to the CA no more than twentyeight days after the agreement comes into force. ${ }^{69}$ So if, for example, a group of school children wanted to perform a custom story from their village to a rap beat for their Christmas play, they would be required to go through this cumbersome process. Particularly in remote areas where the reach of the state is weak and communication difficult, this seems a ridiculously bureaucratic process, and one that is significantly disenfranchising of the local customary authorities whose decision is no longer sufficient.

\section{(d) Dispute Resolution}

Although section 33 states that the parties can always use customary law and practice to resolve disputes, customary law is not mandated as a primary forum and the customary institutions are not given any state enforcement powers. It therefore appears highly unlikely that customary law and practice will be able to be used in hotly contested cases, as disputes about forum are likely to undermine its authority. ${ }^{70}$ This is especially the case given the importance for the parties of meeting the statutory timeframe or else risking losing all to the CA.

The above discussion demonstrates that the approach adopted to date by the Model Law is not truly pluralistic, despite the many references to customary

69 Model Law, above n 5, s 25.

70 See Forsyth, above n 10, c 6. 
law. At almost every turn, the state has been given a central role and customary institutions marginalised. Before discussing the problems that may arise from this, it is useful to reflect on why this approach has been adopted and to assess how much justification there is for it. The primary reason for its adoption is that customary institutions are perceived to be uncertain and difficult to access, whereas centralising control in the state has the apparent benefits of simplicity and efficiency. Thus a state-based system is seen to facilitate access to TK by outsiders. $^{71}$ A legislative reform whose only objective is the commercialisation of TK by outsiders may therefore prioritise a state-based approach, but it may be only a short-term solution because it may lead to the undermining of TK itself. The state is also seen as being more responsible and capable of making decisions to benefit the population as a whole. However, the example of the Tongan state entering into an agreement with a multinational company to collect samples of blood from its population for gene research, ${ }^{72}$ and the high levels of government corruption in the region, show that the state is not necessarily to be implicitly trusted. Involvement of the state is also seen to be a safeguard against communities entering into unfair agreements with outsiders due to an imbalance in bargaining power. This is certainly a legitimate point, but safeguarding the communities against unfair contracts should be targeted with a great deal more precision than the current legislation does. Yet again this points to the necessity of clearly identifying the aims of the legislation, and perhaps separating competing aims into different pieces of legislation.

\section{Potential Problems Arising from the Lack of a Deep Pluralist Approach}

The preceding section demonstrated the lack of real engagement with customary institutions and law by the Model Law. This section discusses a range of problems that could arise if the legislation were implemented nationally in its present form. Drahos and Braithwaite remind us that this type of cost-benefit exercise is extremely important in the field of intellectual property, but that assessing the disadvantages of intellectual property protection is often overlooked while the advantages of greater levels of protection are emphasised..$^{73}$ As a general point, it may be said that the approach currently adopted by the Model Law shares many of the characteristics of traditional intellectual property legislation. However,

71 Lindstrom, above n 30, 298-99.

72 M Smith, 'Population-Based Genetic Studies: Informed Consent and Confidentiality' (2001-2002) 18 Santa Clara Computer \& High Technology Law Journal 57, 70. See also Sister K A Kanongata'a, 'Autogen and Bio-Ethics in Tonga: An Ethical and Theological Reflection' in A Mead and S Ratuva (eds), Pacific Genes and Life Patents (Call of the Earth Llamado de la Tierra, United Nations University- Institute of Advanced Studies, 2007) 166

73 Drahos with Braithwaite, above n 8, ix. 
as Posey argues, such laws are 'inadequate and inappropriate for protection of traditional ecological knowledge and community resources' because, inter alia, 'they simplify ownership regimes, stimulate commercialisation, are difficult to monitor and enforce, and are expensive, complicated and time-consuming. ${ }^{174}$

\section{(a) The New Framework Undermines Customary Institutions and Thus TK Itself}

The inter-relationship between customary institutions, TK, and the social and economic basis of communities has been discussed above. The very intrusion of the state into this field threatens these important relationships, as it introduces a competing source of authority. One of the chief concerns with the Model Law is that it puts the evolution of TK into the state's hands, because it is the state that is deciding the threshold questions about what is customary and what is not. It thus usurps a very important role for customary institutions: that of finding a path through the challenges of modernity whilst maintaining those traditional values that continue to be of importance to the local community. It also undermines customary institutions by requiring the involvement of the state (through the CA) in every non-customary use of TK by the community, thus again cutting across the authority of the local institutions. As mentioned above, existing customary institutions are fragile in the region, and there is a real possibility that challenges to their authority by the state may cause them to break down altogether. As I demonstrated in another study in the context of criminal law, where there are two competing sources of authority (state and customary) there is a great temptation to avoid the authority of each by using one to criticise the legitimacy of the other. ${ }^{75}$ The worst possible outcome would be for the new state structures to aid the disappearance of existing regulatory structures, but to be unable to provide an effective replacement due to the weakness of the state that characterises much of the region.

\section{(b) Fostering of Community Division}

There is a very great risk that the Model Law and other initiatives in the Action Plan, such as the creation of databases, may become a catalyst for internal conflicts. Claims over ownership of particular traditional practices, particularly where there is a hope of economic benefit, have the potential to cause considerable community tension. Strathern argues:

74 D Posey, 'Commodification of the Sacred Through Intellectual Property Rights' (2002) 83 (1-2) Journal of Ethnophramacology 3, 9.

75 Forsyth, above n 11, c 6 . 
Intellectual property rights seem a poor social register and may even set people against one another. If the identification of individual authors or inventors becomes problematic in light of traditional authorship and collective inventions, then the identification of individual property holders becomes problematic in the light of multiple claims. Even if a group can be identified, who belongs to the group? Who is the representative to speak on its behalf? What about power inequalities between different interests within the group ${ }^{76}$

The problem of disputes has already arisen in a database initiative in Fiji run by the Ministry of Indigenous Affairs. Reflecting on this programme, the Director of the Institute of Fijian Language and Culture notes that disputes by communities over ownership are an ongoing problem. ${ }^{77}$ Such considerations make it essential that clear avenues for dealing with such disputes are firmly in place. Unfortunately, as discussed above, this is an area where the Model Law is extremely unclear.

The links between intellectual property and opportunistic behaviour recently outlined by Drahos also have application here. ${ }^{78}$ Thus, the monopolistic approach set up in the legislation, whereby one group wins absolute access over TK (without even a limited time period, as in Western-style intellectual property legislation), is likely to promote rent-seeking behaviour by the particular 'owners' that will cause further divisions within society and restrict the traditional structures for the diffusion of TK. Moreover, by positivising TK by law and state bureaucracy, a number of well-known regulatory difficulties (for example, regulatory capture of patent offices) are potentially opened up, and these may be particularly problematic in developing countries because of weak and/or corrupt state institutions.

\section{(c) Unreasonably Raised Expectations}

A related problem is that the push towards protecting TK may create unreal expectations of benefit amongst the local population. To an extent, this has already started. For example, the popular magazine Island Business stated: 'If one were to evaluate commercial potential beginning from the metaphysics to blood cells and going out to cultural expressions, flora and fauna, Pacific Islanders are sitting on a gold mine. They just don't fully comprehend it yet. ${ }^{179}$

76 M Strathern, 'Multiple Perspectives on Intellectual Property' in K Whimp and M Busse (eds), above n $31,47,51-52$.

77 M Qereqeretabua, above $\mathrm{n} 51$.

78 P Drahos, above n 24, 30.

79 D Tabureguci, The Pacific's Stolen Identity: How Intellectual Property Rights have Failed Pacific Cultures (2007) < http://www.islandsbusiness.com/islands_business/index_dynamic/containerNameToReplace=Middl eMiddle/focusModuleID=18144/overideSkinName=issueArticle-full.tpl $>$ 
Strathern similarly comments: 'Intellectual property has suddenly become a topic of widespread international interest. Moreover, once articulated it rapidly catches the public imagination, and this is something to be taken into account in policy development. ${ }^{80}$

There is a need to make sure there are realistic expectations about the probably modest amount of profit that TK commercialisation is likely to bring, following commentators such as Dutfield who have cautioned: 'it is important not to overestimate the economic potential of $\mathrm{TK}^{\prime}{ }^{81}$ It is likely that envisaged gains will in no way be comparable to the cultural richness that could be lost by interfering with the current dynamic tradition of community-based exchange and use of TK.

\section{(d) The Problem of TK Already in the Public Domain}

A question that has not been clearly addressed by the Model Law is how to deal with the problem of TK that has already spread from its ancestral location (if such can be located) and is being used in various places within a country or even outside the Pacific Island countries. ${ }^{82}$ The people from the Fijian island of Beqa, for example, claim that the firewalking ceremony known as vilavilairevo belongs to them, and they have already started a campaign to get it back (that is, stop it being performed by other groups). ${ }^{83}$ If it can be established that they are the 'owners' of the ceremony, the Model Law would require that no one else will be able to perform it without the consent of the Beqa people. ${ }^{84}$ The effect of this (and similar situations) on the livelihood of countless tourist-based businesses throughout the Pacific, and the fierce disputes it would engender, are disturbing to contemplate. The only gain may be that preparing court cases will be a very good way of revitalising traditional knowledge, as exemplified by the 'Sawau Project', which was established to document the process and demonstrate its origin in Beqa.

\footnotetext{
80 Strathern, above n 76, 47.

81 G Dutfield, 'Developing and Implementing National Systems for Protecting Traditional Knowledge: Experiences in Selected Developing Countries' in S Twarog and P Kapoor (eds), Protecting and Promoting Traditional Knowledge: Systems, National Experiences and International Dimensions (United Nations Publication, 2004) 141, 144.

82 It could be argued that attempting to regulate this is like trying to shut the paddock gate after the horse has bolted, although the example of the recent success some European countries have had in re-gaining protection for commodities such as cheese and wine through the movement for GIs and appellations of origin may contradict this. However, to achieve such successes, significant economic bargaining power is required. 83 K Hennessy, 'A Ituvatuva Ni Vakadidike E Sawau: The Sawau Project DVD' (2009) 25(1) Visual Anthropology Review 90. The author of this article states, 'The Sawau project was conceived as a strategy for repatriating ownership of Sawau cultural heritage back to its place of origin on the island of Beqa, Fiji'. See also G Pigliasco, above n 48, 255.

84 Section 3 of the Model Law provides that it applies to TK that was in existence before the commencement of the Act.
} 
In Palau this issue is dealt with in the TK Bill by requiring all pre-existing noncustomary uses to be registered with the relevant Ministry within 180 days of the legislation taking effect. Then, commencing one year after the legislation has been in force, users of such TK are required to attach a label to objects that embody the TK, stating, 'This product includes elements of Palauan traditional knowledge or expressions of culture which have been used without the express guidance or approval of the traditional owner' or to make a speech at the start of a performance to the same effect. ${ }^{85}$ It can be imagined how unpalatable this would be to the local tourist industry, and could be the reason the Bill has not as yet been promulgated.

\section{(e) Stifling of Internal Research, Use and Development of TK by TK Owners Themselves}

One of the greatest dangers is that the legislation and associated initiatives could impede the current dynamic exchange and development of TK. There is a risk that such an initiative will foster a commercialisation mentality in which people seek to guard 'their' TK in order to profit from it in the cash economy. Dutfield observes that 'modern IPR [intellectual property rights] reflect, but also help to underpin (through the rewards they provide) a highly competitive winner-takeall business ethos', ${ }^{86}$ and similar concerns arise in respect of the Model Law's determination of ownership by finite groups of people. Once again, the parallels with the social problems following the leasing of customary land and resources development in Melanesia are only too apparent. As mentioned above, if the free movement of TK between communities is impeded, this will diminish the cultural richness of the society as a whole and impede the evolution of TK. It is likely also to have negative impacts upon many aspects of people's livelihood which depend on the use of TK, such as primary health care and agriculture. ${ }^{87}$

The legislation could also have a curtailing effect on research that is currently being conducted by both indigenous researchers and foreign scholars. For example, the Vanuatu Fieldworkers, a network of indigenous researchers established by the Vanuatu Cultural Centre, conduct research on a different aspect of TK within their own communities each year. ${ }^{88}$ If they are required to comply with the formalities of the legislation (and there is no reason why they should not, as conducting research is not a 'customary use'), then this is likely

85 Ibid, s 26(a).

86 Dutfield, above $\mathrm{n} 81,145$

87 Ibid, 142-143. Dutfield notes that the WHO has stated that 80 per cent of the world's population depends on traditional medicine for its primary healthcare and that TK is indispensable for its survival.

88 See, for example, D Tryon and V K Senta (eds), Woksop Blongol Filwoka Ples blong ol pig long kastom laef long Vanuatu: buk 1 [Customary pig pens in Vanuatu: Book 1, Vanuatu Cultural Centre's Fieldworkers Workshop] (Vanuatu KaljoralSenta, 1990). 
to have a stifling effect on this important initiative. Surely the most important aim of any TK initiative is to keep TK alive, and so any procedures that make it more difficult for local people to use it should be avoided? How can communities share TK and learn and innovate if they are always up against a state authority? Although it may be argued that the law will be only selectively enforced, and so groups such as the Vanuatu Fieldworkers would not be in danger, this is not satisfactory for a variety of reasons, including the fact that criminal sanctions may possibly be involved..$^{89}$

One of the particular problems in this regard is the enormously wide scope of the legislation: it aims to cover every conceivable type of TK and to provide rights over it in perpetuity. Whilst such an approach makes sense for certain types of TK, such as secret or sacred material, it appears unduly restrictive overall. A different approach is suggested by Dutfield, who states:

Ideally the protectable subject matter should be defined in close consultation with the purported beneficiaries. Also, the broader the definition of TK, the more the rights provided should be limited in some way or another ... to treat all conceivable categories of TK as deserving strong and/or permanent protection is unreasonable and would almost certainly go beyond what customary law indicates anyway. ${ }^{90}$

In carrying out such a consultation, views of authors such as Boyle who demonstrate the importance of a wide public domain to generate new works should also be shared. ${ }^{91}$ There is no reason why the careful balancing of rights of users and rights of the public that lies at the heart of Western-style intellectual property protection should not also be of relevance in the context of TK. One possible way of avoiding some of the identified dangers would be to extend the moral rights provisions to commercial and non-commercial use, but otherwise to tailor the provisions much more narrowly to meet specific objectives, such as preventing one person gaining a commercial advantage at the expense of others.

\section{What Would a True Deep Pluralistic Approach Look Like?}

A review of the international literature on TK protection does not currently provide a shining example of a national model of protection based on respect and support for customary norms and institutions. Much of the literature is contextualised within an indigenous rights narrative wherein the indigenous

89 The penalty provisions in sections 26-29 provide imprisonment as a possible penalty.

90 Dutfield, above n 81, 142.

91 Boyle, above $\mathrm{n} 7$. 
population is currently suppressed by a dominant other - but this is not the case in Pacific Island countries. Given this rare ability to exercise rights from a position of power, ${ }^{92}$ the Pacific Island countries have a degree of liberty to shape a new approach to protection of TK that other indigenous groups may follow. Of course, this liberty is likely to be reduced as a result of multilateral and bilateral trade negotiations currently underway. ${ }^{93}$ The aim of this section is to outline a particular path that may be followed to arrive at such a model of protection.

A true pluralist approach to the protection of TK would follow a bottom-up process, and would emerge following widespread consultations with community and customary leaders as a first step. This approach has the support of a recent global study into protecting and promoting TK, the editors of which state: 'There is general consensus that new approaches and measures (sui generis systems) that combine tools in an appropriate way need to be developed for the protection of TK at the national and international levels ... These systems should be developed in close consultation with indigenous and local communities. ${ }^{94}$ The benefits of such an approach appear self-evident, but to date this step has been neglected in most TK initiatives around the world. Thus Dutfield comments on 'how rare it is for indigenous peoples and local communities to be consulted about new [TK] legislation' ${ }^{95}$ This consultation would address a number of preliminary questions such as the desire and need for greater protection of TK, and the types of support existing customary institutions require to meet the needs identified.

As the substantive composition of the legal framework to emerge from such consultations cannot be known until those consultations have occurred, it is not possible to pre-empt it in any great detail. It is, however, possible to discuss and describe some of the principles that are likely to underpin any development emerging from such a process.

\section{(a) Customary Institutions Supported and Strengthened}

The empowering of customary institutions and leaders to develop their processes and norms for regulating use of TK, both within and without their community, is likely to be central to any new protection system. Thus Solomon argues in the context of Māori laws: 'First priority needs to be given to strengthening and protecting customary law systems, because of the important values inherent in those systems, which are critical to the maintenance of the cultures concerned. ${ }^{96}$

92 D Conway, 'Indigenizing Intellectual Property Law: Customary Law, Legal Pluralism, and the Protection of Indigenous Peoples' Rights, Identity and Resources' (2008-2009) 15 Texas Wesleyan Law Review 207, 208. 93 Such as the European Partnership Agreement and the 'PACER Plus' negotiations with Australia. See M Penjueli and W Morgan, 'Putting Development First: Concerns about a Pacific Free Trade Agreement' (2010) 25(1) Pacific Economic Bulletin 211.

94 Twarog and Kapoor, above n 45, xv.

95 Dutfield, above $\mathrm{n} 81,150$.

96 M Solomon, above n 45, 155, 164. 
Such a model would involve a decentralised, locally based decision-making structure with responsibility for determining questions of access and equitable benefit sharing, rather than a state-centred one as envisaged in the Model Law. Swiderska, in her work with the International Institute for Development, argues:

The best way for communities to protect their knowledge and resources is at local level. Community-based natural resource management, together with secure land-tenure, can strengthen community control of TK and natural resources, maintain traditional knowledge, conserve biodiversity and improve livelihoods.

She gives the example of the community-based Andean Potato Park that uses customary principles of reciprocity, equilibrium and duality to guide the management of the park at the local level. ${ }^{97}$ Peter Ørebech similarly argues that customs that develop customary law systems 'play a critical role in achieving viable social systems' ${ }^{98}$

As part of this process it will be necessary to create space for discussions with customary leaders about the competing aims of conservation and commercialisation, and developing processes that are able to mediate between these different demands while retaining key cultural principles. This is best done by creating a dialogue that seeks to facilitate an informed engagement with the issues, and avoids using the language of 'theft' and 'ownership'. Pacific Islanders are extremely inventive, and many of their customary leaders are very wise and informed by deep understandings of their communities and the forces at play within them. There is therefore every chance that, given the opportunity, they will come up with solutions unexpected to an outsider but which will work for their community. For example, Geismar has illustrated how, through a judicious use of traditional beliefs and practices, a group of men from North Ambrym ensured that the market in carved wooden gongs (tam-tams) for which they are famous has remained effectively in their hands. ${ }^{99}$

\section{(b) Minimal State Intervention}

The state does have an important role to play in a truly pluralistic protection model, but it is as an advisor and facilitator, and not as a primary regulator. There are many useful functions the state can have, especially in regard to mediating between its citizens and outsiders who wish to use TK. The state may also need to develop processes by which it can assist local customary authorities in enforcing any decisions they have made concerning TK. In addition, it may

97 K Swiderska, 'Banishing the Biopirates: A New Approach to Protecting Traditional Knowledge' (2011) International Institute for Development Gatekeeper Series 129, 16-17.

98 P Ørebech et al (eds), The Role of Customary Law in Sustainable Development (Cambridge University Press, 2005) 9.

99 H Geismar, 'Copyright in Context: Carvings, Carvers and Commodities in Vanuatu' (2005) 32(3) American 
also work on initiatives such as developing systems of certification marks for different communities. It also has an important role in small island states as a gatekeeper, making sure that the activities of researchers and developers are monitored and opportunities for exploitation minimised - for example, through a system of research permits as currently operate in Vanuatu and Fiji. Finally, the state could ensure that its import rules forbid the importation of goods embodying the TK of the country, thus ensuring that only citizens of the country can profit from making such objects. ${ }^{100}$

\section{(c) Diffuse Benefit Sharing from Use of TK}

A pluralist approach would encourage the benefits from TK being spread among as many communities and individuals as possible. This would be done by promoting the spirit of communal benefit that underlies TK in the Pacific Islands as a whole. For example, a land dispute in Vanuatu may traditionally have been resolved by allowing the 'losing' party to remain on a part of the land that was under contestation, whereas a court-adjudicated approach would require the winner to take all. ${ }^{101}$ A similar approach is advocated by Swiderska, who argues that: 'Given that TK and genetic resources are often shared freely between communities, even across borders, collective rights, decision-making and benefit-sharing amongst neighbouring communities should be recognised.' ${ }^{102}$

\section{(d) Promoting the Use of TK by Local Communities}

A central aim of a pluralist approach to protection is to facilitate access by local communities to their own TK, and to the TK of neighbouring communities, in accordance with reciprocal customary obligations. Any expensive or bureaucratic process that may work as an impediment to this should be avoided. The primary aim should be to use TK to improve the livelihoods of TK holders and communities through contributing to a rich cultural life, ecologically sound agricultural practices and primary health care. This approach is similar to that of the 'traditional economy' advocated by Vanuatu MP Regenvanu, who argues that it is constantly overlooked by policy-makers but has in fact been the major source of resilience for Melanesian populations for thousands of years. ${ }^{103}$

\footnotetext{
100 For example, if tam-tams were being made in Bali and shipped back to Vanuatu for sale in the tourist market, this would be prohibited by such restrictions.

101 Regenvanu states that in the traditional Melanesian economy 'everyone has access to land on which to make gardens for food and access resources, even people with no traditional claim over the land being used. However, the ill-considered alienation of land from the traditional economy in Vanuatu through leasehold titles, for example, is removing the means for ordinary people to be economically productive and enjoy food and social security.' Regenvanu, above n 26, 5 .

102 Swiderska, above n 97, 17.

103 Regenvanu, above n 26.
} 
Indigenous Peoples' Innovation

\section{Conclusion}

The aim of this chapter has been to suggest that the current move to protect TK in the Pacific Island countries is taking a wrong direction in giving the state such a central role, and in prioritising the commercialisation of TK over use of TK by local communities. The brakes need to be applied and a deeper reflection made into the issues through a process of widespread community consultation. The current initiative is proceeding as if TK is terra nullius, whereas in fact each country in the region has a sophisticated customary legal system in which TK is deeply embedded. This chapter suggests that the first step in any move to protect TK should be to enquire into this system, and to see if and how it could be empowered to meet the new challenges posed to TK by globalisation. One significant advantage of doing this is that it will also support the underlying social and economic structures that produce TK. On the other hand, a failure to do so may very well risk undermining the customary structures that have led to the extraordinary wealth of TK in the region in the first place. 